\title{
STUDY ON CAUSES OF DELAY AND COST OVERRUNS IN HERITAGE RENOVATION OF BHAKTAPUR
}

\author{
Umesh Sukamani $^{1}$, Hari Mohan Shrestha ${ }^{2}$ \\ ${ }^{I}$ Department of Civil Engineering, Khwopa Engineering College, Libali-8, Bhaktapur, Nepal \\ ${ }^{2}$ Department of Construction Management, Nepal Engineering College, Prayagpokhari, Nepal
}

\begin{abstract}
A fresh and present look at the performance and delivery of heritage projects is required because few studies have been conducted to explore the specific project management and participant issues that contributed failed elements (time and cost) in heritage projects. The major contribution of this research is in the guidance for improvement to help avoid delays and cost overruns in future heritage renovation projects. Bhaktapur municipality is rich in heritage; here the tourism market is one of the source of economy. Bhaktapur municipality has been selected for this study because many of the heritage renovation projects have been completed each year. Most of heritage renovations have been done with the help of users committee and amanat. Tourism has become an important economic factor for the region. So the heritage renovation is studied with the impact of the delay in the works. The research design for this study is more qualitative than quantitative. The main causes of delay have been found as difficulties in financing projects and poor managerial skills. Similarly, the causes of the cost overruns have been found as material cost increased due to inflation.
\end{abstract}

Keywords: Heritage renovation, Delay analysis, Cost overruns, Bhaktapur municipality

\section{Introduction}

The step to protect ancient properties, that are regarded as forming part of a country's national heritage, has grown immensely since the World Heritage Centre and the World Heritage list were both established in 1972 (UNESCO, 1972). The importance of old heritage sites has been recognized worldwide and analyzed by many researchers (Araoz, 2011); (Brand, 1995); (Forster and Kayan, 2009); (Orbagli, 2008); (Rypkema, 2003). Different heritage organizations have since been founded with the goal of protecting and managing cultural heritage, and different studies have explained the importance of preserving and protecting old heritage architecture. The necessity to preserve the aesthetic quality of heritage buildings and their outstanding universal value is emerging as a task of high importance for governments and the professional

\footnotetext{
*Corresponding author: Umesh Sukamani

Department of Civil Engineering, Khwopa Engineering

College, Libali-8, Bhaktapur, Nepal

Email:umesh_sukamani@yahoo.com

(Received: Nov 27, 2017 Accepted: May 20, 2018)
}

discipline that runs heritage projects. (Mason, 2005; Provins, 2008 and Roders, 2011).

Managing heritage projects has been seen as a complex issue, sometimes facing significant criticism (Reyers, 2001). Today, there is growing reception that heritage conservation provides cultural, economic and social benefits to urban communities. Moreover, heritage buildings are seen as an important element of Bhaktapur's social capital (Bullen, 2011). Bhaktapur municipality highlighted the importance of taking actions to protect heritage places from further developmental activities in order to retain their values. Heritage projects management is necessary to execute meeting time and cost obligations; this drags towards the need for investigation of current project management systems to obtain better outcomes in heritage projects.

The present study attempts to address certain critical activities in the current management of the planning or design phase of the project lifecycle of heritage 
renovation, which is considered necessary in the successive construction phases, and thereby, it contributes significantly to control project cost overruns and time delays. Although supporting principles, policies and guidance to improve heritage renovation project outcomes have been developed. Many problems still occur to seriously affect the management of heritage renovation projects.

A new and fresh look at the project performance and delivery of heritage projects is necessary, as few studies have been conducted to explore the specific project management and the role of active stakeholders that contributed to delays and cost overruns.

Despite the results from previous research that have been utilized to provide solutions to improve the delivery of heritage renovation projects, many such projects are in fact still running time overrun and cost overrun. Meeting the time and cost limits is often found even in the well-managed projects that are run by experienced managers and supported by highly regarded organizations. After fifteen years of collecting data, (Shenhar, 2007) came up with the surprising result that 85 percent of all construction projects have failed to meet time and budget goals. A main task of the research is to identify the major causes of delays and cost overruns in heritage renovation and to identify causes of how current processes and procedures can be improved to better fit the heritage project to ensure the completion on time and within budget.

Researcher mainly focused on major causes of delay as Client related factors that include finance management and payments of completed work and delay in decision making; Contractors related factors include the site management, improper planning, adequate construction experience, and correct execution during construction, proper construction methods followed and subcontracting the work system. Consultants related factors include contracts management, preparation and approval of drawings, quality assurance control and timely approval of tests and inspections; materials factors include quality and availability; labour and equipment factor include labour supply, labour productivity and equipment availability and maintenance; contractual relationships factors include major disputes resolution and negotiations during construction, appropriate and functional organizational structure linking all parties involved in the project and effective communication between these parties; external factors include weather conditions, changes in regulations, problems with neighbors and site conditions.

Tourism plays an important role in the economy of Bhaktapur municipality. This study finds that cultural tourism in Bhaktapur has contributed to local government's tax revenue particularly through tourist entry fee which in turn contribute in the conservation of the world heritage properties.

People are always captivated by newness and wants of the new thing in a normal case. So, with the changing lifestyle the house owners also want a modern lifestyle with cables, solar panels, underground water tanks, roof-top tanks and as such which World Heritage Site rules do not allow. With these conflicting interests and noncompliance of rules and regulations take place leading to loss of the uniqueness of its heritage.

All the three Durbar Squares in Bhaktapur are in good condition. Local people of Bhaktapur are aware of the knowledge of conservation of heritages. During the study, it was found that the site manager had more contact with the locals. People also have realized the importance of conservation, but they wish for incentives. The locals of Bhaktapur Dubar Square have decided not to sell their houses to outsiders. This also may be the reason for the intactness of urban space as every resident is the people born and brought up with the Newari tradition and the surroundings.

\section{Methodology}

\subsection{Study Area}

The Bhaktapur municipality has population about 77,000 inhabitants and is located at a distance of 16 $\mathrm{km}$ east of Kathmandu. Besides Kathmandu and Lalitpur, it is the only ancient Newari town, and is one of the three old royal cities in the valley.

Its location on the main caravan route between Tibet and India had made the city prosperous and brought 
a certain impulse to the development of cultural life. Nowadays, relics of this multifaceted cultural and architectonical history are the main reasons for domestic and foreign tourists to visit the city.

Tourism has become an important economic factor for this municipality. Another important economic sector in Bhaktapur municipality is agriculture. About $60 \%$ of the city's population are members of the Jyapu caste and working mainly as farmers (many of them in subsistence), although Bhaktapur is a medium size city (Taraschewski, 2007).

In Bhaktapur, the renovation works of heritage by the users' committee was started on 049/50 fiscal year. Data form the Bhaktapur magazine, 208 renovation works were studied which were renovated from year of 2055 B.S to till date which shows the renovation works of about 71 percentage of the renovation projects are within the budget and time. The study is conducted for further improvement in renovation works within budget and time.

\section{Map of Bhaktapur Municipality}

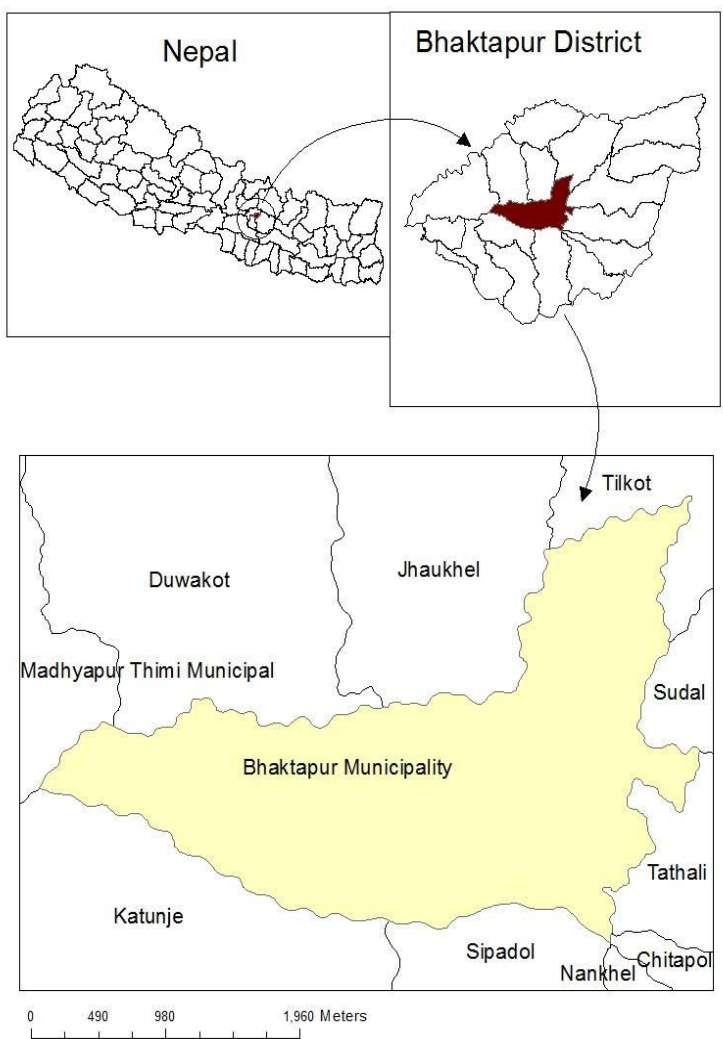

Fig 1 Location of Bhaktapur municipality

\subsection{Current Management Practices of Old Heritage Renovation Projects:}

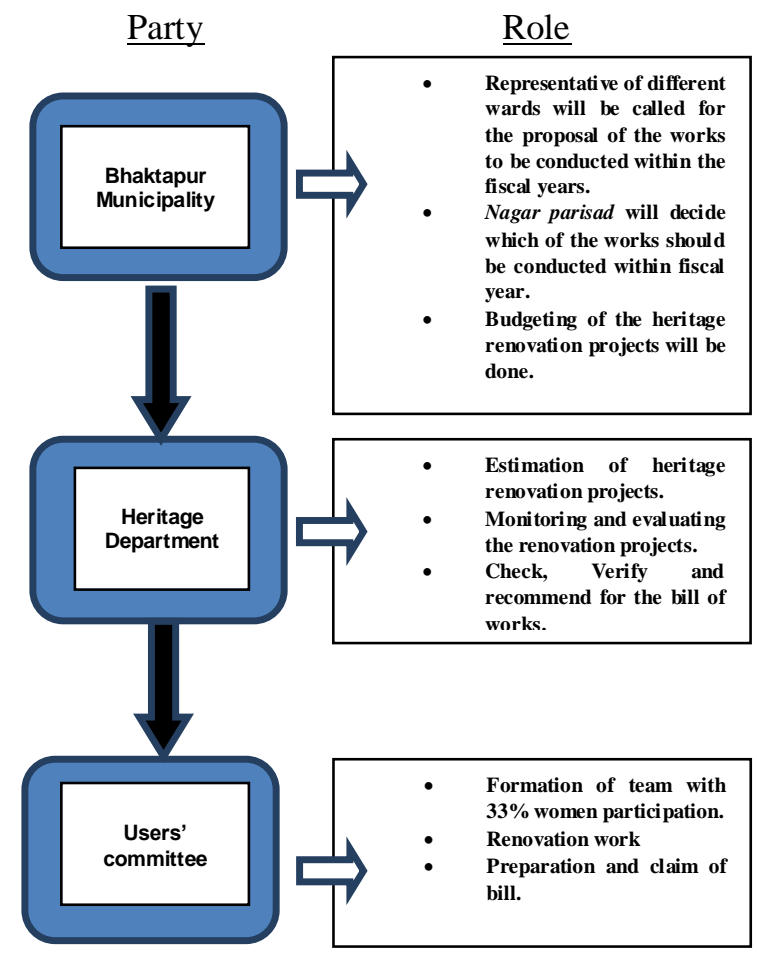

Fig 2 Current management practices of old heritage renovation projects

\section{Sampling for Interview with Key-role Personnel}

For sampling for interview with key-role personnel, officials from various projects were interviewed as per questionnaire developed. The officials are either chairpersons of the renovation project or individuals assigned by chairperson. The sampling in this case was purposive or judgmental sampling, done on researcher's intuition and subjective and relevance basis.

\section{Sampling for Interview with Archaeology Department Officials, Bhaktapur Municiplaity}

Sub overseers and Architects from Archaeology department officials in Bhaktapur Municiplaity were selected for interview and discussion. For the study, the researcher conducted interviews with Mr. Surya Bhakta Kharbuja, Technical Advisor, Archeology Department, Bhaktapur Municipality, who was involved in all the renovation projects.

For research, Mr. Kharbuja acts as a member of Bhaktapur Municiplaity. 


\section{Sampling for Questionnaires with Individuals (end members)}

For questionnaire to respond, the researcher met individuals, and interviewed individuals from different walks of life as per questionnaire developed. Random sampling technique was used in this case for selecting the samples. Although the number of samples is too small compared to the entire population, the number has been restricted due to similarity of responses from all individuals involved and also due to limitation of time.

\subsection{Data collection techniques}

For the purpose of this study, the various types of data to be collected includes primary data through observations and questionnaires and interviews with key members of concerned heritage renovation projects, and direct and indirect beneficiaries of projects were conducted. Municipality members, representatives of political parties, intellectuals, local people etc. were the beneficiaries. Secondary data from existing laws, rules and regulations, literature review, existing cases, previous relevant studies in Bhaktapur municipality, etc. were considered.

\subsection{Data Analysis Techniques}

In the present study, the collected data was analyzed by using SPSS tools and Qualitative Data Analysis Technique. The study involves Qualitative Data in the form of information gathered in a non-numerical form like people and their activities and views, signs, symbols, interview transcript, field notes, images and documents (report, meeting minutes etc.). The most common forms of qualitative data were what people have said or done.
Using Qualitative Data Analysis technique, the raw data is collected in some form of explanation, understanding or interpretation of the people under investigation. Qualitative Data Analysis then the meaningful and symbolic content of qualitative data was evaluated and interpretation was developed to categorization and analytical understanding to draw the conclusions.

\section{Result and Discussion}

\subsection{Correlation Analysis}

In this study, the Pearson Correlation coefficient was used to test the presence of association between the variables. Values between 0 and 0.3 ( 0 and -0.3 ) indicate no correlation (variables not associated), 0.3 and $0.5 \quad(-0.3$ and -0.5$)$ a weak positive (negative) linear association, Values between 0.5 and $0.7(-0.5$ and -0.7$)$ indicate a moderate positive (negative) linear association and Values between 0.7 and 1.0 (- 0.7 and -1.0) indicate a strong positive (negative) linear association. The significance of the relationship is tested at $95 \%$ level with a 2-tailed test where a statistically significant 33 correlation is indicated by a probability value of less than 0.025 . This means that the probability of obtaining such a correlation coefficient by chance is less than 2.5 times out of 100, so the result indicates the presence of an association.

\subsection{Most Important Delaying Parameters:}

From the respondents, SPSS analysis was done taking the very high linear association with correlation value greater than 0.9 to 1.0 are taken. There is $25 * 2=50$ number of very high correlation data. And it indicates following variables as a major parameter of delay analysis.

Table 1 Important cost overruns parameters

\begin{tabular}{|l|l|l|c|c|}
\hline S.No. & \multicolumn{2}{|c|}{ Correlation between } & $\begin{array}{c}\text { Correlation } \\
\text { value }\end{array}$ & $\begin{array}{c}\text { Level of } \\
\text { significance }\end{array}$ \\
\hline 1 & Increase environmental restriction & poor relationship with sub-contractor & 0.922 & 0.009 \\
\hline 2 & $\begin{array}{l}\text { Poor cost control of site } \\
\text { management }\end{array}$ & $\begin{array}{l}\text { Cost of accident: damages, injury and } \\
\text { death }\end{array}$ & 0.944 & 0.005 \\
\hline 3 & Lack of resource planning & Material cost increased by inflation & 0.905 & 0.013 \\
\hline 4 & Lack of resource planning & Increase in labor cost & 0.944 & 0.005 \\
\hline 5 & Claims and dispute with clients & poor team work relation & 0.976 & 0.001 \\
\hline 6 & Material cost increased by inflation & poor team work relation & 0.937 & 0.006 \\
\hline
\end{tabular}


Table 2 Correlation between important delaying parameters

\begin{tabular}{|c|c|c|c|c|}
\hline S.No. & Correlation between & & Correlation & Level of \\
\hline 1 & Difficulties in financing project & Wind damages & 0.913 & 0.014 \\
\hline 2 & Difficulties in financing project & $\begin{array}{l}\text { Hot weather effect on construction } \\
\text { activities }\end{array}$ & 0.903 & 0.014 \\
\hline 3 & Difficulties in financing project & $\begin{array}{l}\text { Delay in performing final inspection } \\
\text { and certification }\end{array}$ & -0.953 & 0.003 \\
\hline 4 & Difficulties in financing project & $\begin{array}{l}\text { Delay in obtaining permits for } \\
\text { construction }\end{array}$ & 0.943 & 0.005 \\
\hline 5 & $\begin{array}{l}\text { Delay in producing design } \\
\text { documents }\end{array}$ & $\begin{array}{l}\text { Ineffective planning and scheduling of } \\
\text { project }\end{array}$ & 0.932 & 0.007 \\
\hline 6 & $\begin{array}{l}\text { Delay in producing design } \\
\text { documents }\end{array}$ & $\begin{array}{l}\text { Delay in obtaining permits for } \\
\text { construction }\end{array}$ & 0.943 & 0.005 \\
\hline 7 & $\begin{array}{l}\text { Unclear and inadequate details in } \\
\text { drawings Design }\end{array}$ & Poor site management & 1.000 & 0.000 \\
\hline 8 & $\begin{array}{l}\text { Unclear and inadequate details in } \\
\text { drawings Design }\end{array}$ & Poor Managerial Skills & 0.921 & 0.009 \\
\hline 9 & $\begin{array}{l}\text { Unclear and inadequate details in } \\
\text { drawings Design }\end{array}$ & Poor Subcontractor Performance & 0.932 & 0.007 \\
\hline 10 & $\begin{array}{l}\text { Misunderstanding of } \\
\text { municipality requirements }\end{array}$ & $\begin{array}{l}\text { Delay in performing final inspection } \\
\text { and certification }\end{array}$ & 0.913 & 0.011 \\
\hline 11 & $\begin{array}{l}\text { Inadequate design-team } \\
\text { experience }\end{array}$ & $\begin{array}{l}\text { Ineffective planning and scheduling of } \\
\text { project }\end{array}$ & 09.55 & .0003 \\
\hline 12 & $\begin{array}{l}\text { Inadequate design-team } \\
\text { experience }\end{array}$ & $\begin{array}{l}\text { Late in selection of finishing materials } \\
\text { due to availability of many types in } \\
\text { market }\end{array}$ & 0.968 & 0.002 \\
\hline 13 & $\begin{array}{l}\text { Un-use of advanced engineering } \\
\text { design software }\end{array}$ & Conflicts between parties & 0.922 & 0.009 \\
\hline 14 & Change Order & $\begin{array}{l}\text { Late in selection of finishing materials } \\
\text { due to availability of many types in } \\
\text { market }\end{array}$ & 0.922 & 0.009 \\
\hline 15 & Wind Damage & $\begin{array}{l}\text { Hot weather effect on construction } \\
\text { activities }\end{array}$ & 1.000 & 0.000 \\
\hline 16 & $\begin{array}{l}\text { Rain effect on construction } \\
\text { activities }\end{array}$ & Poor Managerial Skills & 09.52 & 0.003 \\
\hline 17 & Fire & $\begin{array}{l}\text { Changes in material types and } \\
\text { specifications during construction }\end{array}$ & 0.955 & 0.003 \\
\hline 18 & $\begin{array}{l}\text { Poor communication and } \\
\text { coordination on site }\end{array}$ & Poor Subcontractor Performance & 0.919 & 0.010 \\
\hline 19 & Poor site management & Poor Managerial Skills & 0.929 & 0.009 \\
\hline 20 & Poor site supervision & Poor Managerial Skills & 0.932 & 0.007 \\
\hline 21 & Slowness in decision making & Late procurement of materials & 1.000 & 0.000 \\
\hline 22 & $\begin{array}{l}\text { Rework due to errors during } \\
\text { construction }\end{array}$ & $\begin{array}{l}\text { Changes in material types and } \\
\text { specifications during construction }\end{array}$ & 0.958 & 0.003 \\
\hline 23 & $\begin{array}{l}\text { Improper construction methods } \\
\text { implemented }\end{array}$ & Poor Managerial Skills & 0.952 & 0.003 \\
\hline 24 & $\begin{array}{l}\text { Changes in government } \\
\text { regulations and laws }\end{array}$ & Seasonal employment & -1.000 & 0.000 \\
\hline 25 & Shortage of labors & Personal conflicts among labours & 0.931 & 0.007 \\
\hline
\end{tabular}


From the above analysis of data, it was found that the numbers of variables affecting the delaying in

the renovation projects are repeated numbers of times. Among them these three variables repeated the most are given in the Table no. 3 below.

Table 3 Most affecting parameters for Delay

\begin{tabular}{|c|l|c|}
\hline S.No & Variables & $\begin{array}{l}\text { No. of } \\
\text { repetition }\end{array}$ \\
\hline 1 & Poor Managerial Skills & 10 \\
\hline 2 & $\begin{array}{l}\text { Difficulties in financing } \\
\text { project }\end{array}$ & 8 \\
\hline 3 & $\begin{array}{l}\text { Unclear and inadequate } \\
\text { details in drawings }\end{array}$ \\
\hline
\end{tabular}

From the above analysis, it is clearly seen that the renovation is affected by Poor Managerial skills, Difficulties in financing projects and Unclear and Inadequate details in drawings.

\subsection{Most Important Cost Overruns Parameters:}

From the respondent, SPSS analysis was done taking the very high linear association with correlation value greater than 0.9 to 1.0 . There is $6 * 2=12$ number of very high correlation data. And it indicates variables as the most important cost overruns parameters as shown in table 1 .

From the above analysis data, it was found that the numbers of variables affecting the cost overruns in the renovation projects are repeated numbers of times. Among them these three variables repeated the most, they are:

Table 4 Most important cost overruns parameters

\begin{tabular}{|l|l|c|}
\hline S.No & Variables & $\begin{array}{l}\text { No. of } \\
\text { repetition }\end{array}$ \\
\hline 1 & $\begin{array}{l}\text { Lack of resource } \\
\text { planning }\end{array}$ & 4 \\
\hline 2 & $\begin{array}{l}\text { Material cost increased } \\
\text { by inflation }\end{array}$ & 4 \\
\hline 3 & $\begin{array}{l}\text { Poor team work } \\
\text { relation }\end{array}$ & 4 \\
\hline
\end{tabular}

From the above analysis, it is clearly seen that the renovation is affected by lack of resource planning, material cost increased by inflation and poor team work relation.

\subsection{Impacts of Cost Overruns:}

From the respondent, SPSS analysis was done taking the very high linear association with correlation value greater than 0.9 to 1.0 are taken. From analysis, it is seen that there is a very correlation between surplus amount and claim with correlation value of 0.953 and level of significance of .0003 . That means it is clearly seen that there is a high impact of cost overruns in surplus amount and the claim for this renovation project.

\subsection{Chance of Occurrence of Delay in Heritage Renovation Projects:}

Table 5 Chance of occurrence of delay in heritage renovation projects

\begin{tabular}{|l|l|l|}
\hline & No. & Percentage \\
\hline Always & 2 & 28.57 \\
\hline Sometimes & 5 & 71.43 \\
\hline Never & 0 & 0.00 \\
\hline
\end{tabular}

From the respondents it is seen that $28.57 \%$ of the projects contains always the delay in heritage renovation projects and $71.43 \%$ of the projects contain sometimes in delay in heritage renovation projects.

\subsection{Main Causes of Cost Overruns:}

Table 6 Main causes of cost overruns

\begin{tabular}{|l|l|l|}
\hline & No. & Percentage \\
\hline Materials & 6 & 40.00 \\
\hline Labour & 6 & 40.00 \\
\hline Sub contractor cost & 2 & 13.33 \\
\hline Job overhead & 1 & 6.67 \\
\hline Total & 15 & 100 \\
\hline
\end{tabular}

From the respondents, it is seen that the major causes of delay in heritage renovation projects are due to materials and shortage of labor as $40 \%$ each. 


\subsection{Anticipation or Prediction of Price Escalation}

From the respondents, it is clearly seen that there is very less percentage of $28.57 \%$, that they tried to anticipate or predict price escalation. It is the worst condition, in which engaged people are not aware of prediction of the price escalation.

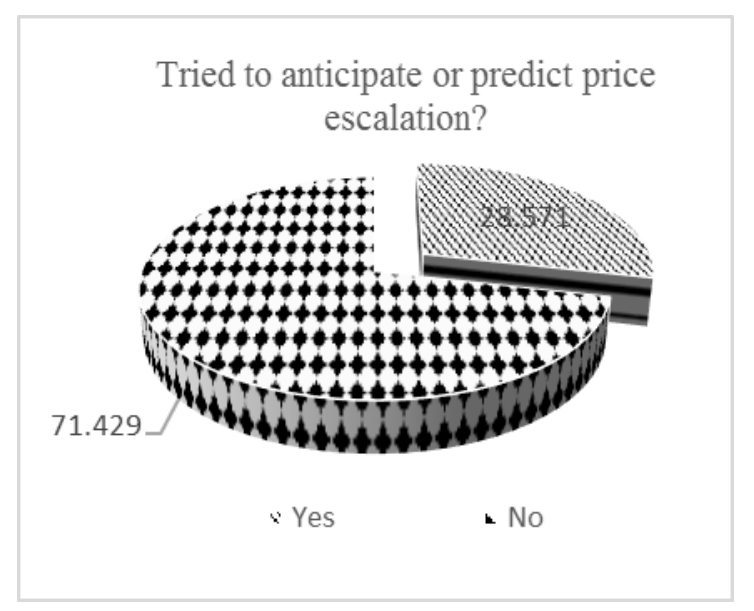

Fig 3 Tried to anticipate or predict price escalation in renovation

\subsection{Parties Affected by Price Escalations:}

From the above Fig. 4, it can be explained that the price escalation will be affected to client and regularity bodies as heritage department and Bhaktapur municipality.

\section{Conclusion}

1. In conclusion, it is found that in the heritage renovation projects, the main delaying factor is difficulties in financing project. And other major factors can be taken as poor managerial skills, conflicts between parties, personal conflicts among labours, and lack of productivity due to ritual festivals \& works.

2. The main causes of the cost overruns is analysed as a material cost increased by inflation. And another major important factor causing the cost overruns is due to the increase in labour cost, lack of resource planning and poor team work relation.

3. The Bhaktapur municipality is affected by the delay and cost overruns of the heritage renovation projects. As Bhaktapur is rich in cultural and rituals works, tourism is one of the source of the Bhaktapur municipality. So, the municipality should maintain its property in time.

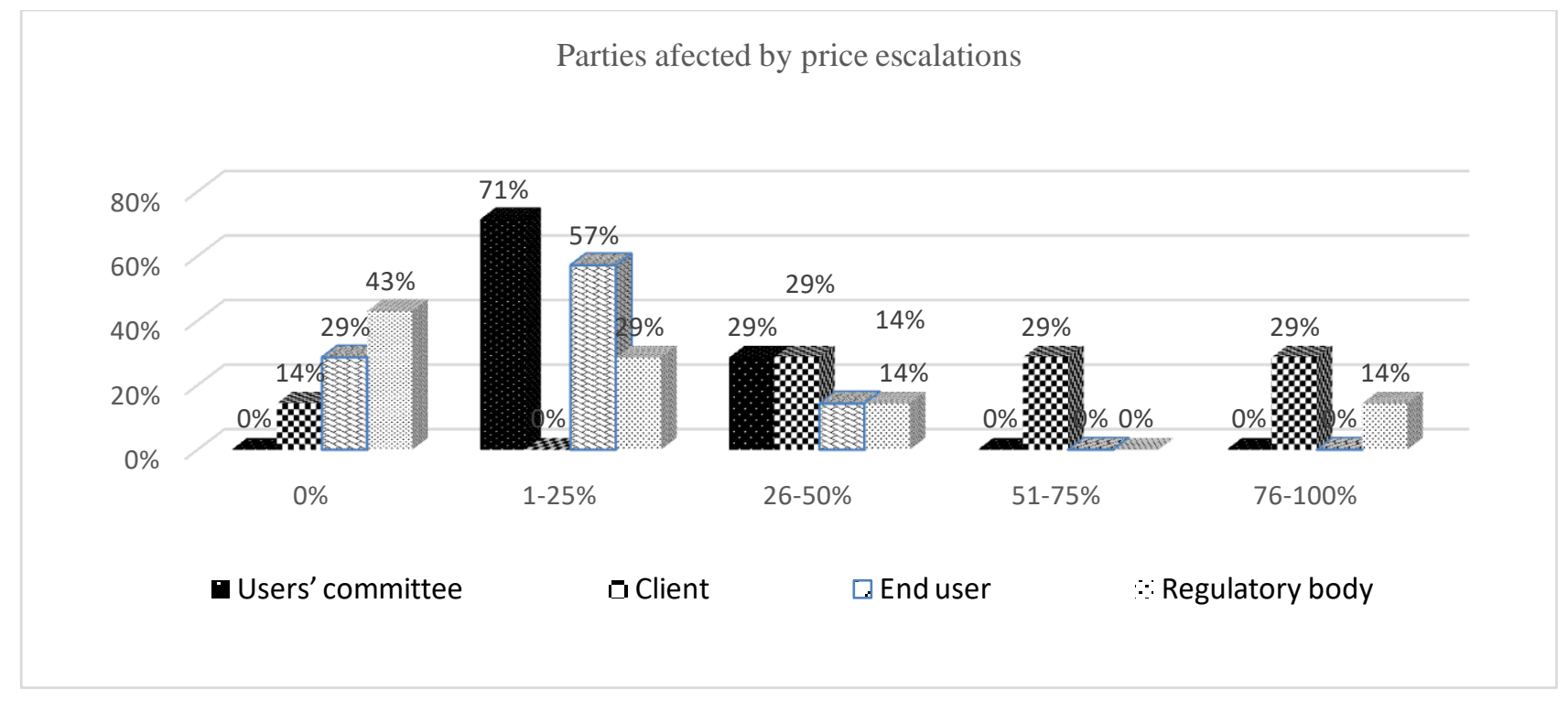

Fig 4 Parties affected by price escalations 


\section{References}

[1] Araoz, G. F. ( 2011). Preserving heritage places under a new paradigm. Journal of cultural, 55-60.

[2] Brand, S. (1995). How buildings learn: What happens after they're built. Penguin Books.

[3] Bullen, P. A. \& Love P. E. D. (2011). Adaptive reuse of heritage buildings. Structural survey 29 (5), 411-421.

[4] Forster, A. M. \& Brit, K. (2009). Maintenance for historic buildings: a current. Structural Survey, vol. 27, no. 3, 210-229.

[5] Mason, R. (2005). Economics and historic preservation. Washington, DC: The Brookings.

[6] Orbagli, A. (2008). Architectural conservation. Blackwell Publishing.

[7] Provins, Allan \& Pearce, David \& Ozdemiroglu, Ece \& Mourato, Susana \& Morse-Jones, Sian ( 2008). Valuation of the historic environment: the scope for using economic valuation evidence in the appraisal of heritage-related projects. Progress in planning, vol. 69, no. $4,131-175$.

[8] REYERS, J. \& Mansfield, J ( 2001). The assessment of risk in conservation refurbishment project. Structural Survey, 19, 238-244.

[9] Roders, A. P. \& Oers, R. V. (2011). World Heritage cities management. Facilities, vol. 29, no., 276-285.

[10] Rypkema, D. D. (2003). Planning for the Future, Using the Past: The Role of Historic. National Trust for preservation.

[11] Shenhar, A. J. \& Dvir, D (2007). The Diamond Approach To Successful Growth And Innovation. Boston, Massachusetts: Harvard Business School Press.

[12] Taraschewski, D.T. (2007). Finalcial Analysis of Bhaktapur Municiplaity, Bhaktapur: Urban Development through Local Efforts Programme.

[13] UNESCO. (1972). The General Conference of the United Nations Educational, Scientific and Cultural Organization meeting in Paris from 17 October to 21 November 1972, at its seventeenth session. Fund for the Protection of the World Cultural and Natural Heritage. 